\title{
Modul Pembelajaran Sains dengan Pendekatan Inkuri untuk Mengembangkan Keterampilan Proses Sains Dasar Siswa Tunarungu
}

\author{
${ }^{1}$ Trisna Mulyeni, ${ }^{2}$ Leliana Lianty \\ ${ }^{12}$ Universitas Negeri Jakarta, Indonesia \\ Email:trisna_mulyeni@unj.ac.id
}

\section{INFORMASI ARTIKEL}

Terkirim 02-April-2021

Revisi 07-April-2021

Diterima 25-April-2021

\section{Kata kunci:}

Pembelajaran Sains;

Keterampilan Proses Sains

Dasar; Inkuiri; Tunarungu

\begin{abstract}
ABSTRAK
Penelitian ini bertujuan untuk menghasilkan produk bahan ajar bagi guru, berupa modul untuk mengembangkan keterampilan proses sains dasar siswa tunarungu. Keterampilan proses sains merupakan aspek yang penting dalam pembelajaran sains. Agar dapat memahami pelaksanaan pembelajaran keterampilan proses sains bagi siswa tunarungu dengan baik, guru membutuhkan bahan ajar yang relevan. Untuk itu dilakukan pengembangan modul pembelajaran sains melalui pendekatan inkuiri, khususnya untuk mengembangkan keterampilan proses sains dasar siswa tunarungu. Tujuan khusus dari penelitian ini adalah untuk mengetahui kelayakan modul yang dikembangkan. Penelitian ini menggunakan metode Research \& Development. Subjek penelitian ini adalah guru dan siswa kelas V SDLB tunarungu. Instrumen yang dikembangkan adalah instrumen untuk uji validasi produk yang diberikan kepada ahli. Analisis data dilakukan secara kualitatif dan kuantitatif. Hasil uji validasi ahli menunjukkan bahwa modul mempunyai rata-rata tingkat kelayakan $87 \%$ atau tergolong pada kriteria sangat layak.
\end{abstract}

\begin{abstract}
The aim of the study was to produce teaching material as a learning module for teachers, in order to develop basic science process skill for hearing impairments students. Science process skills are an important aspect in learning science. Teachers need teaching materials as a source of relevant knowledge and skills in order to implement science learning especially in developing science process skills. For this reason, a specific module was developed for teachers to teach science process skills through an inquiry approach for hearing impairments students. Specific aim of the study was to examine the feasibility of the module as a product being developed. This study used the method of Research \& Development. The subjects of the study were classroom teachers and fifth grade of hearing impairments students. An instrument for product validation testing was developed and given to relevant experts. Data analysis was carried out qualitatively and quantitatively. The results of the expert validation test showed that the module has a feasibility level of $87 \%$, which categorized as a very feasible product.
\end{abstract}

\section{Pendahuluan}

Pendidikan merupakan aspek yang penting bagi segala usia, begitu juga dengan anak-anak termasuk anak berkebutuhan khusus seperti anak tunarungu. Anak tunarungu merupakan anak yang mengalami hambatan dalam hal pendengaran. Mereka mengalami keterlambatan dalam perkembangan bahasa, kosa kata dan literasi (Luckner et al., 2012). Pada umumnya siswa tunarungu tertinggal dalam berbagai bidang pelajaran. Siswa tunarungu diperkirakan mengalami ketertinggalan selama sekitar 
tiga setengah tahun dibandingkan dengan siswa yang pendengarannya normal (Wood et al dalam Kritzer 2009). Di Indonesia pembelajaran untuk siswa tunarungu diselenggarakan melalui pembelajaran tematik, yakni dengan mengintegrasikan pembelajaran dalam tema dan subtema. Sains atau Ilmu Pengetahuan Alam (IPA) merupakan salah satu pelajaran yang diberikan di tingkat Sekolah Dasar termasuk di Sekolah Luar Biasa (SLB). Sains merupakan aspek yang penting dalam kehidupan manusia. Kemajuan dalam bidang sains dan teknologi diawali dari pendidikan bidang sains. Untuk itu pembelajaran sains seyogyanya mendapat perhatian agar dapat dilaksanakan dengan lebih baik.

Menurut Martin (2009), sains didefenisikan sebagai suatu proses yang menghasilkan produk, sehingga ada dua aspek yang harus diperhatikan dalam pembelajaran sains, yakni proses dan produk. Produk sains dapat berupa konsep, fakta, teori atau produk berupa aplikasi (Martin, 2009). Proses dalam sains melibatkan keterampilan proses sains. Keterampilan proses sains adalah serangkaian keterampilan intelektual dalam mengumpulkan informasi disekitar dengan cara yang terpercaya (Brunton \& Thornton, 2010). Keterampilan proses sains dasar, merupakan keterampilan yang diperlukan dalam mengerjakan sains (Bentley et al., 2007; Martin, 2009; Rezba et al., 2007). Keterampilan proses sains memungkinkan siswa untuk memproses informasi baru melalui pengalaman konkret.

Keterampilan proses sains merupakan aspek yang penting, tidak hanya untuk pembelajaran sains dan pembelajaran lainnya di kelas, namun juga untuk kehidupan sehari-hari (Mechling and Oliver, 1983 dalam Carin, Bass, and Contant, 2005). Penguasaan keterampilan ini juga memungkinkan siswa untuk melakukan keterampilan proses untuk tingkatan yang lebih tinggi pada jenjang pendidikan selanjutnya. Salah satu aspek keterampilan proses sains dasar yang penting adalah keterampilan mengobservasi. Menurut Martin (2009), mengobservasi merupakan keterampilan dalam mengumpulkan informasi dengan menggunakan pancaindra yang tepat (Carin et al., 2005; Martin, 2009).

Aspek proses sains seringkali dianggap lebih penting dari pada aspek produk (Martin, 2009). Walaupun dianggap penting, kenyataannya pada pembelajaran ditingkat awal lebih cenderung pada aspek pengetahuan atau aspek produk. Hal ini juga terlihat dari metode pembelajaran yaitu dengan cara berceramah di depan kelas. Berdasarkan wawancara dan penyebaran angket pada guru mengenai pelaksanaan pembelajaran sains di kelas tunarungu, diketahui bahwa pembelajaran belum difokuskan untuk keterampilan proses sains dasar. Dengan demikian, sudah seyogyanya dilakukan pengembangan keterampilan proses sains dasar siswa tunarungu.

Guru sebagai pendidik di sekolah memegang peranan penting dalam mengembangkan keterampilan proses sains. Dalam hal ini guru menentukan aktivitas pembelajaran termasuk pembelajaran sains yang terkait dengan keterampilan proses sains dasar. Pengembangan keterampilan proses sains dapat dilakukan dengan memberi kesempatan pada siswa untuk melakukan aktivitas sains. Guru dapat memilih aktivitas dan menentukan pendekatan yang digunakan dalam pembelajaran, termasuk untuk pengembangan keterampilan proses sains dasar. Dengan demikian, dapat dikatakan bahwa guru memegang peranan penting dalam melatih dan mentransfer keterampilan proses sains kepada siswa. 
Salah satu cara yang dapat digunakan guru untuk mengembangkan keterampilan proses sains dasar siswa adalah dengan menggunakan pendekatan inkuiri dalam pembelajaran sains. National Science Education Standard mendefenisikan inkuiri saintifik (scientific inquiry) sebagai berbagai cara yang digunakan oleh ilmuwan dalam mengeksplorasi alam dan mengajukan penjelasan berdasarkan bukti-bukti yang diperoleh melalui penyelidikan (Houtz, 2008). Inkuiri merupakan salah satu pendekatan yang dianggap penting dalam pembelajaran sains. Pembelajaran melalui pendekatan inkuiri dapat membekali siswa dengan keterampilan dan pengetahuan sains. Hal ini memungkinkan siswa untuk dapat menjadi pembelajar yang mandiri sepanjang hayat (Llewellyn, 2002). Selanjutnya, pembelajaran sains melalui pendekatan inkuiri dapat menggunakan keterampilan proses sains dalam ekplorasinya. Dengan demikian, siswa dapat berlatih menggunakan keterampilan proses sains dalam konteks aktivitas sains.

Penelitian tentang pembelajaran sains melalui pendekatan inkuiri telah dilakukan diberbagai jenjang pendidikan. Hasil penelitian menunjukkan bahwa skor hasil belajar siswa lebih baik melalui pembelajaran berbasis inkuiri dari pada metode yang konvensional (Abdi, 2014). Penelitian juga menunjukkan bahwa pembelajaran berbasis inkuiri dapat meningkatkan hasil belajar sains secara signifikan (Aktamiş et al., 2016). Selain meningkatkan hasil belajar, pendekatan inkuiri juga dapat meningkatkan keterampilan proses sains. Hasil penelitian menunjukkan bahwa pembelajaran berbasis inkuiri dapat meningkatkan keterampilan proses sains pada siswa kelas V (Şimşek \& Kabapınar, 2010), siswa kelas IV, V dan VI (Ergül et al., 2011) dan siswa kelas II (Mulyeni et al., 2019).

Hasil penelitian-penelitian sebelumnya menunjukkan dampak positif dari pelaksanaan pembelajaran sains melalui pendekatan inkuri, baik untuk hasil belajar maupun untuk keterampilan proses sains. Selain untuk kelas regular, pembelajaran sains melalui pendekatan inkuiri juga direkomendasikan untuk siswa tunarungu. Wang (2011) menyatakan bahwa pembelajaran sains melalui pendekatan inkuri, memungkinkan siswa tunarungu untuk mengembangkan keterampilan berpikir dan konsep ilmiah. Implikasi penelitian menunjukkan dukungan agar pelaksanaan pembelajaran sains bagi siswa tunarungu dilakukan melalui pendekatan inkuiri (Raven \& Whitman, 2019). Pembelajaran yang melibatkan siswa dalam inkuiri dapat meningkatkan literasi siswa yang mempunyai kemampuan bahasa terbatas serta dapat meningkatkan hasil belajar dalam sains (Im \& Kim, 2014).

Untuk melaksanakan pembelajaran sains melalui pendekatan inkuri, guru harus memiliki kompetensi tertentu (Alake-Tuenter et al., 2013). Hasil penelitian mengimplikasikan bahwa pembelajaran pada siswa berhubungan dengan kompetensi guru (Vikström, 2008). Dalam pembelajaran sains melalui pendekatan inkuri, guru membutuhkan kompetensi yang dikategorikan dalam tiga kelompok yakni: pengetahuan terhadap materi pelajaran, sikap dan pengetahuan pedagogi konten (Alake-Tuenter et al., 2012). Hasil penelitian menunjukkan bahwa guru mestinya diberikan kesempatan untuk mengintegrasikan pengembangan kompetensi mengenai pengetahuan sains, sikap dan keterampilan mengajar (Alake-Tuenter et al., 2013). Selanjutnya penelitian berupa survey juga menunjukkan bahwa guru membutuhkan dukungan berbagai metodologi pembelajaran, agar lebih efektif dalam melaksanakan pembelajaran sains kepada anak berkebutuhan khusus (Irving et al., 
2007). Hal ini menunjukkan pentingnya pengembangan kompetensi guru dalam pembelajaran sains melalui pendekatan inkuri.

Guru kelas di SLB pada umumnya mempunyai latar belakang pendidikan khusus. Guru kelas memberikan pembelajaran sains di kelas bersama-sama pembelajaran lainnya melalui pembelajaran tematik. Selanjutnya dari hasil wawancara peneliti dengan guru dan hasil angket yang diberikan terhadap guru kelas tunarungu, diketahui bahwa pembelajaran keterampilan proses sains dasar belum diintegrasikan dalam pembelajaran sains secara terstruktur. Dengan demikian pembelajaran lebih cendrung pada aspek pengetahuan yang bersumber pada guru dan buku teks tematik. Untuk dapat melaksanakan pembelajaran sains khususnya untuk aspek keterampilan proses sains dasar, diperlukan pemahaman tentang hakikat pembelajaran sains dan cara-cara melaksanakannya sesuai dengan hakikatnya. Selanjutnya hasil dari wawancara dan angket yang diberikan menunjukkan bahwa guru membutuhkan pengembangan wawasan pengetahuan mengenai cara melaksanakan pembelajaran sains melalui pendekatan inkuiri, khususnya untuk aspek keterampilan proses sains dasar.

Salah satu upaya untuk meningkatkan kompetensi guru adalah dengan memfasilitasi sumber belajar yang dapat dijadikan pedoman. Salah satu bahan ajar yang dapat digunakan adalah buku berupa modul. Modul adalah bahan ajar yang disusun secara sistematis dengan bahasa yang mudah dipahami oleh pembelajar sesuai tingkat pengetahuan dan usia. Modul disusun agar pembelajar dapat belajar secara mandiri dan tidak banyak memerlukan bantuan atau bimbingan (Prastowo, 2016). Bagian-bagian isi modul disusun untuk dapat dipelajari secara sistematis dan bertahap. Dengan demikian, pembelajar dapat mempelajari materinya secara lengkap. Guru SLB tunarungu mempunyai latar belakang akademik sebagai sarjana bidang pendidikan khusus. Dengan demikian, guru mempunyai potensi untuk mampu menjadi pembelajar yang mandiri, sehingga modul dapat dipahami dan digunakan. Modul dapat membantu guru dalam mengembangkan keterampilan mengajar (Mufidah \& Susilawati, 2019). Untuk itu peneliti mengembangkan modul sebagai sumber belajar untuk memperluas wawasan dan pemahaman guru tentang pembelajaran sains melalui pendekatan inkuiri, khususnya untuk mengembangkan keterampilan proses sains dasar siswa tunarungu.

Tujuan dari penelitian ini adalah, (a) menghasilkan produk berupa modul pembelajaran sains melalui pendekatan inkuiri, yang ditujukan untuk guru SLB tunarungu; (b) mengetahui tingkat kelayakan modul yang dikembangkan. Keutamaan dari penelitian ini adalah menghasilkan modul yang layak untuk dapat dijadikan sumber belajar dan pedoman bagi guru dalam melaksanakan pembelajaran sains untuk mengembangkan keterampilan proses sains dasar siswa tunarungu. Penguasaan wawasan dan keterampilan guru terhadap materi modul yang dikembangkan, diharapkan dapat membawa dampak yang positif dalam pembelajaran sains siswa tunarungu, termasuk aspek keterampilan proses sains dasar.

\section{Metode}

Penelitian ini merupakan jenis penelitian dan pengembangan atau Research and Development $(R \& D)$ untuk menghasilkan suatu produk berupa modul bagi guru. Prosedur penelitian dan pengembangan terdiri dari langkah langkah sebagai berikut: (1) potensi dan masalah, (2) pengumpulan data, (3) desain produk, (4) validasi desain, (5) revisi desain, (6) uji coba produk, (7) revisi produk, (8) 
uji coba pemakaian (9) revisi produk, dan (10) produksi masal (Sugiyono, 2017). Penelitian ini dilaksanakan sampai pada tahap kelima yakni tahap revisi desain produk. Subjek penelitian adalah guru kelas V dan siswa kelas V SLB Negeri 7 Jakarta.

Instrumen penelitian yang dikembangkan adalah angket yang diberikan pada guru SLB, yang digunakan untuk mengumpulkan data tentang hal-hal yang berkaitan dengan pelaksanaan pembelajaran sains bagi siswa tunarungu. Selain itu peneliti juga mengembangkan instrumen validasi produk yang diberikan kepada ahli materi pembelajaran tunarungu, ahli desain instruksional dan ahli bahasa Indonesia. Teknik pengumpulan data yang dilakukan adalah wawancara dan pemberian angket kepada guru kelas, serta pemberian instrumen validasi pada ahli yang terkait.

Pada tahap awal, peneliti menggali potensi dan masalah tentang pelaksanaan pembelajaran sains untuk siswa tunarungu. Peneliti melakukan pengumpulan data melalui wawancara dan pemberian angket pada guru. Selain itu, pengumpulan data juga dilakukan dari dokumen berupa kurikulum. Data tahap awal ini digunakan untuk analisis kebutuhan sebelum produk dikembangkan. Pada tahap selanjutnya, untuk mengetahui kelayakan produk, data dikumpulkan melalui pemberian angket pada ahli materi, ahli desain instruksional dan ahli bahasa Indonesia.

Analisis data dilakukan dengan menggunakan pendekatan kualitatif dan kuantitatif. Analisis deskriptif kualitatif digunakan untuk mengolah data hasil wawancara, dan saran oleh para ahli. Analisis data kualitatif dijadikan sebagai acuan untuk pengembangan dan revisi modul. Analisis data kuantitatif dilakukan dari hasil uji angket validitas ahli pada pengembangan modul. Analisis ini dilakukan dengan membandingkan jumlah skor yang telah diberikan oleh ahli $\left(\sum R\right)$ dengan jumlah skor ideal yang telah ditetapkan di dalam angket validasi $(\mathrm{N})$. Rumus penghitungan yang digunakan adalah sebagai berikut:

$$
\begin{aligned}
& P=\underset{\mathrm{N}}{\sum \mathrm{R}} \times 100 \% \\
& \mathrm{P}=\text { Presentase skor hasil validasi } \\
& \sum \mathrm{R}=\text { Jumlah skor yang diberikan oleh ahli } \\
& \mathrm{N}=\text { Jumlah skor maksimal }
\end{aligned}
$$

Data hasil uji angket berupa persentase dikonversi menjadi nilai kualitatif untuk mengetahui tingkat kelayakan modul yakni: sangat layak, layak, cukup layak, kurang layak dan sangat kurang layak. Kategori kelayakan modul dapat dilihat pada Tabel 1 berikut ini.

Tabel 1. Kriteria kelayakan produk berdasarkan hasil validasi ahli

\begin{tabular}{ccl}
\hline No & $\begin{array}{c}\text { Rentang Persentase Skor } \\
\text { Perolehan }\end{array}$ & Kriteria Kelayakan \\
\hline 1 & $81-100$ & Sangat layak/Sangat kuat \\
2 & $61-80$ & Layak/ kuat \\
3 & $41-60$ & Cukup layak/cukup \\
4 & $21-40$ & Kurang layak/lemah \\
5 & $0-20$ & Sangat kurang layak/sangat lemah \\
\hline
\end{tabular}




\section{Hasil Penelitian dan Pembahasan \\ Deskripsi Modul}

Penelitian ini menghasilkan produk berupa modul yang berjudul: Pembelajaran Sains Melalui Pendekatan Inkuiri untuk Mengembangkan Keterampilan Proses Sains Dasar Siswa Tunarungu. Modul ini ditujukan bagi guru Kelas V SDLB tunarungu. Modul terdiri dari 43 halaman, ukuran halaman A4 dengan jenis huruf Times New Roman dengan huruf berukuran 12. Bagian-bagian utama modul terdiri dari pendahuluan, materi, dan penutup. Bagian pendahuluan menyajikan deskripsi singkat dari modul, kegunaan, sasaran dan ruang lingkup. Materi modul berupa konsep-konsep hakikat pembelajaran sains dan pelaksanaan pembelajaran sains melalui pendekatan inkuiri. Modul dilengkapi dengan contoh-contoh RPP dan LKS yang terkait dengan pembelajaran sains melalui pendekatan inkuiri bagi siswa tunarungu. Materi pada modul disajikan secara bertahap, mulai dari pemahaman konsep dasar sampai pada pemahaman yang bersifat praktis. Penulisan modul mempertimbangkan konsep mastery learning. Pada konsep mastery learning, pembelajar diarahkan untuk dapat memahami materi yang disajikan secara bertahap (Pribadi \& Putri, 2019).

Materi modul membahas tentang konsep-konsep pembelajaran yang terdiri dari, hakikat sains, keterampilan proses sains dasar, dan pendekatan inkuiri. Hakikat sains menekankan pemahaman mengenai aspek-aspek utama dalam sains yakni sains sebagai produk atau pengetahuan dan sains sebagai proses. Dalam pembelajaran sains, seringkali adanya kecenderungan untuk dominan pada aspek pengetahuan. Untuk itu penjelasan pada materi ini dapat memperkuat pentingnya aspek proses dalam pembelajaran sains. Selanjutnya modul ini menyajikan materi tentang pelaksanaan pembelajaran sains melalui pendekatan inkuiri untuk siswa tunarungu. Pengetahuan pedagogi konten merupakan salah satu aspek kompentesi dari guru dalam pembelajaran sains (Alake-Tuenter et al., 2012).

Pelaksanaan pembelajaran melalui pendekatan inkuiri yang dibahas dalam modul merupakan tingkatan inkuiri yang sederhana. Sesuai dengan yang dikemukakan oleh Bell et al., (2005) bahwa inkuiri dimulai dari tingkatan inkuri yang rendah dan kemudian dikembangkan menuju inkuiri pada tingkatan yang lebih tinggi (Bell et al., 2005). Fase-fase pembelajaran yang disajikan pada modul dilengkapi dengan penjelasan tentang aktivitas yang dilakukan guru dan siswa dalam pembelajaran. Hal ini disebabkan karena dalam pembelajaran melalui inkuiri mempunyai karakteristik tertentu, baik dari aspek aktivitas siswa maupun aktivitas guru. Salah satu karakteristik dalam pembelajaran sains melalui pendekatan inkuiri adalah melakukan penyelidikan. Untuk itu peneliti memberikan contohcontoh aktivitas penyelidikan serta contoh objek atau bahan yang digunakan dalam pembelajaran sains. Contoh aktivitas pembelajaran yang disajikan bersifat konkret dan sederhana sehingga diharapkan dapat diikuti oleh siswa tunarungu. Aktivitas yang bersifat konkret sangat relevan dengan pembelajaran bagi siswa tunarungu (Luckner et al., 2012).

Materi modul ini dilengkapi dengan contoh RPP dan LKS yang disesuaikan dengan kurikulum yang digunakan. Contoh RPP dan LKS yang diberikan terkait dengan keterampilan proses sains dasar. Penelitian sebelumnya menggunakan LKS yang dapat melibatkan siswa dalam menggunakan keterampilan proses sains (Aktamis \& Ergin, 2008). Contoh LKS yang diberikan dalam modul dilengkapi dengan gambar-gambar sebagai petunjuk visual. Penggunaan gambar dan bahasa tertulis 
merupakan hal yang penting untuk memperkuat komunikasi dengan siswa tunarungu dalam pembelajaran (Luckner et al., 2001). Pada LKS juga diintegrasikan pengenalan kosa kata yang terkait dengan pembelajaran sains. Pengenalan kosa kata dianggap perlu karena siswa tunarungu mengalami keterbatasan dalam kosa kata. Penulisan LKS menggunakan huruf tegak bersambung dan menggunakan bahasa yang sederhana. Hal ini mendukung pembelajaran untuk siswa tunarungu yang pada umumnya mempunyai keterlambatan dalam perkembangan bahasa.

\section{Kelayakan dan Revisi Modul}

Pada tahap pengembangan dalam penelitian ini, modul divalidasi oleh ahli yang terkait, yakni ahli materi pembelajaran tunarungu, ahli desain instruksional dan ahli Bahasa Indonesia. Hasil angket dari validasi ahli dapat dilihat pada pada Tabel 2 di bawah ini.

Tabel 2. Hasil angket validasi ahli materi, ahli desain instruksional dan ahli bahasa

\begin{tabular}{|c|c|c|c|c|c|}
\hline Ahli & No & Aspek & $\begin{array}{l}\text { Validitas } \\
(\%)\end{array}$ & $\begin{array}{c}\text { Rerata } \\
\text { Validitas } \\
(\%)\end{array}$ & Kriteria \\
\hline \multirow[t]{6}{*}{ Materi } & 1 & $\begin{array}{l}\text { Relevansi dengan } \\
\text { kurikulum }\end{array}$ & 100 & \multirow{6}{*}{89} & \multirow{6}{*}{ Sangat layak } \\
\hline & 2 & Penyajian materi & 80 & & \\
\hline & 3 & $\begin{array}{l}\text { Konsep hakikat pembelajaran } \\
\text { sains }\end{array}$ & 90 & & \\
\hline & 4 & $\begin{array}{l}\text { Konsep pelaksanaan } \\
\text { pembelajaran }\end{array}$ & 83 & & \\
\hline & 5 & Sikap dalam pembelajaran & 100 & & \\
\hline & 6 & Evaluasi & 80 & & \\
\hline Desain & 1 & Tujuan pembelajaran & 87 & \multirow{4}{*}{85} & \multirow{4}{*}{ Sangat layak } \\
\hline \multirow[t]{3}{*}{ Instruksional } & 2 & Strategi pembelajaran & 80 & & \\
\hline & 3 & $\begin{array}{l}\text { Penyusunan bahan } \\
\text { pembelajaran }\end{array}$ & 85 & & \\
\hline & 4 & Desain modul & 87 & & \\
\hline \multirow[t]{5}{*}{ Bahasa } & 1 & Huruf yang digunakan & 100 & \multirow{4}{*}{86} & \multirow{4}{*}{ Sangat layak } \\
\hline & 2 & Kalimat yang digunakan & 80 & & \\
\hline & 3 & Ejaan, kosa kata, Istilah & 75 & & \\
\hline & 4 & Relevansi dan makna & 90 & & \\
\hline & & Rerata & & 87 & Sangat layak \\
\hline
\end{tabular}

Pada Tabel 2 dapat diketahui hasil kelayakan modul berdasarkan validasi ahli materi, ahli desain instruksional dan ahli bahasa Indonesia. Rata-rata kelayakan dari validasi ahli adalah $87 \%$, dengan kriteria sangat layak. Selanjutnya peneliti melakukan beberapa perbaikan pada modul 
berdasarkan saran dan komentar dari ahli materi, ahli desain instruksional dan ahli bahasa Indonesia.

Hasil dari validasi ahli materi pembelajaran tunarungu, diperoleh rata-rata sebanyak $89 \%$, dengan kriteria sangat layak. Ahli materi memberikan saran bahwa pada LKS harus diperhatikan aspek penyampaian yakni bahasa dan jenis gambar yang disajikan. Siswa tunarungu mempunyai keterbatasan dalam berbahasa sehingga perlu diperhatikan penggunaan kata dan kalimat pada LKS. Berdasarkan hal tersebut, kalimat-kalimat yang digunakan harus sederhana sesuai dengan karakteristik siswa. Peneliti melakukan beberapa perbaikan dalam penyajian LKS dari segi bahasa. Sebagai contoh pada LKS sebelum revisi terdapat kalimat: "Bacalah cerita berikut ini bersama guru dan temantemanmu". Kata "berikut ini" dianggap cenderung bersifat abstrak bagi siswa tunarungu. Kalimat tersebut diganti dengan "Bacalah cerita di bawah ini bersama guru dan teman-temanmu". Kata "di bawah" ini pada kalimat tersebut menunjukkan posisi cerita yang akan dibaca tersebut berada di bawah kalimat pada teks.

Selanjutnya saran lain dari ahli materi adalah ilustrasi pada LKS yang berupa animasi diganti dengan gambar yang lebih konkret berupa foto. Penggunaan gambar pada LKS merupakan salah satu aspek yang penting dalam pembelajaran untuk siswa tunarungu. Hal ini disebabkan karena siswa tunarungu menerima informasi dalam pembelajaran, lebih bersandar pada faktor penglihatan mereka. Penggunaan gambar sebagai petunjuk visual dapat meningkatkan komunikasi dengan siswa.

Dari aspek desain instruksional modul mendapat hasil kelayakan 85\%, yang tergolong pada kriteria sangat layak. Ahli desain instruksional memberikan saran dalam aspek desain modul terkait dengan jenis huruf yang digunakan. Jenis huruf pada LKS disarankan agar diupayakan lebih kontras. Dalam hal ini peneliti sebelumnya menggunakan jenis font Bradley Hand ITC ukuran 14 dengan warna hitam. Setelah mencoba jenis huruf tegak bersambung lainnya maka diganti dengan jenis font Sogoe Script ukuran 12, dengan warna hitam. Saran lain adalah agar pada tahap evaluasi materi modul dilengkapi dengan kunci jawaban. Dengan demikian, pembelajar dapat mengetahui pencapaiannya dalam menggunakan modul secara mandiri

Berdasarkan validasi dari ahli bahasa, diperoleh hasil kelayakan sebanyak 86\%, dengan kriteria sangat layak. Walaupun demikian, ahli bahasa memberikan saran untuk beberapa penyusunan kalimat agar lebih efektif. Kalimat yang efektif dapat memudahkan pemahaman orang lain secara tepat (Trismanto, 2001). Berdasarkan saran dari ahli bahasa, peneliti melakukan revisi pada modul. Kalimat diperbaiki menjadi kalimat yang lebih efektif. Sebagai contoh, pada LKS terdapat kalimat: "Saya meraba daun: (a) licin (b) keras (c) kasar". Kalimat ini diperbaiki menjadi: "Saya meraba daun terasa: (a) licin (b) keras (c) kasar".

\section{Kesimpulan}

Penelitian ini merupakan penelitian pengembangan (R\&D), yang telah menghasilkan produk bahan ajar bagi guru berupa modul pembelajaran sains melalui pendekatan inkuiri untuk mengembangkan keterampilan proses sains dasar siswa tunarungu. Selain berdasarkan konsep-konsep hakikat pembelajaran sains dan pendekatan inkuiri dalam pembelajaran sains, modul dikembangkan berdasarkan analisis peserta didik dari guru yakni anak berkebutuhan khusus tunarungu. Uji validasi menunjukkan hasil bahwa modul ini mempunyai rata-rata kelayakan 87\% (sangat layak). Modul yang 
dihasilkan ini layak untuk diujicobakan untuk mengetahui efektivitas dari modul.

\section{Ucapan Terimakasih}

Penulis mengucapkan terima kasih kepada pimpinan Universitas Negeri Jakarta dan Fakultas Ilmu Pendidikan atas dukungan yang diberikan untuk terselenggaranya penelitian ini. Penulis juga mengucapkan terima kasih pada seluruh informan dalam penelitian ini.

\section{Daftar Rujukan}

Abdi, A. (2014). The Effect of Inquiry-based Learning Method on Students' Academic Achievement in Science Course. Universal Journal of Educational Research, 2(1), 37-41. https://doi.org/10.13189/ujer.2014.020104

Aktamis, H., \& Ergin, O. (2008). The Effect of Scientific Process Skills Education on Students' Scientific Creativity, Science Attitudes and Academic Achievements. Asia-Pacific Forum on Science Learning and Teaching, 9(1), 1-21.

Aktamiş, H., Hiğde, E., \& Özden, B. (2016). Effects of the Inquiry-Based Learning Method on Students' Achievement, Science Process Skills and Attitudes towards Science: A MetaAnalysis Science. Journal of Turkish Science Education, 13(4), 248-261. https://doi.org/10.12973/tused.10183a

Alake-Tuenter, E., Biemans, H. J. A., Tobi, H., \& Mulder, M. (2013). Inquiry-Based Science Teaching Competence of Primary School Teachers: A Delphi Study. Teaching and Teacher Education, 35, 13-24. https://doi.org/10.1016/j.tate.2013.04.013

Alake-Tuenter, E., Biemans, H. J. A., Tobi, H., Wals, A. E. J., Oosterheert, I., \& Mulder, M. (2012). Inquiry-Based Science Education Competencies of Primary School Teachers: A literature study and critical review of the American National Science Education Standards. International Journal of Science Education, 34(17), 2609-2640. https://doi.org/10.1080/09500693.2012.669076

Bell, R. L., Smetana, L., \& Binns, I. (2005). Simplifying Inquiry Instruction. The Science Teacher, 72(7), 30-33.

Bentley, M. L., Ebert II, E. S., \& Ebert, C. (2007). Teaching Constructivist Science, K-8: Nurturing Natural Investigators in the Standards-Based Classroom. Thousand Oaks, California: Corwin Press.

Brunton, P., \& Thornton, L. (2010). Science in the Early Years, Building Firm Foundations from Birth to Five. SAGE Publications Ltd.

Carin, A. A., Bass, J. E., \& Contant, T. L. (2005). Teaching Science as Inquiry (10th ed.). New Jersey: Person, Merill Prentice Hall.

Ergül, R., Simsekli, Y., Çalis, S., Özdilek, Z., Göçmençelebi, S., \& Sanli, M. (2011). The Effects of Inquiry-Based Science Teaching on Elementary School Students' Science Process Skills and Science Attitudes. Bulgarian Journal of Science and Education Policy, 5(1), 48-68.

Houtz, B. (2008). Teaching Science Today. California: Shell Education.

Im, S., \& Kim, O. J. (2014). An Approach to Teach Science to Students with Limited Language 
Proficiency: in the Case of Students with Hearing Impairment. International Journal of Science and Mathematics Education, 12(6), 1393-1406. https://doi.org/10.1007/s10763013-9465-1

Irving, M. M., Nti, M., \& Johnson, W. (2007). Meeting the Needs of the Special Learner in Science. International Journal of Special Education, 22(3), 109-118.

Kritzer, K. L. (2009). Barely Started and Already Left Behind: A Descriptive Analysis of the Mathematics Ability Demonstrated by Young Deaf Children. Journal of Deaf Studies and Deaf Education, 14(4), 409-421. https://doi.org/10.1093/deafed/enp015

Llewellyn, D. (2002). Inquire Within: Implementing Inquiry-Based Science Standards. Corwin Press Inc.

Luckner, J., Bowen, S., \& Carter, K. (2001). Visual Teaching Strategies for Students Who Are Deaf or Hard of Hearing. Teaching Exceptional Children, 33(3), 38-44.

Luckner, J. L., Slike, S. B., \& Johnson, H. (2012). Helping Students Who are Deaf or Hard of Hearing Succeed. Teaching Exceptional Children, 44(4), 58-67. https://doi.org/10.1177/004005991204400406

Martin, D. J. (2009). Elementary Science Methods: A Constructivist Approach (5th ed.). Belmont: Wadsworth, Cengage Learning.

Mufidah, A. I., \& Susilawati, S. Y. (2019). Modul Bina Diri Tunagrahita untuk Meningkatkan Keterampilan Mengajar Guru Inklusif. Jurnal Ortopedagogia, 5(November), 107-110.

Mulyeni, T., Jamaris, M., \& Supriyati, Y. (2019). Improving Basic Science Process Skills through Inquiry-based Approach in Learning Science for Early Elementary Students. Journal Of Turkish Science Education, 16(2), 187-201. https://doi.org/10.12973/tused.10274a

Prastowo, A. (2016). Pengembangan Bahan Ajar Tematik, Tinjauan Teoretis dan Praktik (Kedua). Jakarta: Penerbit Kencana.

Pribadi, B. A., \& Putri, D. A. P. (2019). Pengembangan Bahan Ajar. Tangerang: Universitas Terbuka.

Raven, S., \& Whitman, G. M. (2019). Science in Silence : How Educators of the Deaf and Hard-ofHearing Teach Science. Research in Science Education, 49, 1001-1012.

Rezba, R. J., Sprague, C. R., McDonnough, J. T., \& Matkins, J. J. (2007). Learning \& Assessing Science Process Skills (5th ed.). Iowa: Kendall/Hunt Publishing Company.

Şimşek, P., \& Kabapınar, F. (2010). The Effects of Inquiry-Based Learning on Elementary Students' Conceptual Understanding of Matter, Scientific Process Skills and Science Attitudes. Procedia Social and Behavioral Sciences, 2, 1190-1194. https://doi.org/10.1016/j.sbspro.2010.03.170

Sugiyono. (2017). Metode Penelitian Pendidikan Pendekatan Kualitatif, Kuantitatif dan R\&D. Bandung: Alfabeta.

Trismanto. (2001). Kalimat Efektif Dalam Berkomunikasi. Majalah Bangun Rekaprima, 2(70), 34.

Vikström, A. (2008). What is Intended, What is Realized, and What is Learned? Teaching and Learning Biology in the Primary School Classroom. Journal of Science Teacher Education, 19, 211-233. https://doi.org/10.1007/s10972-008-9090-y 
Wang, Y. (2011). Inquiry-Based Science Instruction and Performance Literacy For Students Who Are Deaf or Hard Of Hearing. American Annals of the Deaf, 156(3), 239-254. 